\title{
STUDIES ON THE RENAL CONCENTRATING AND DILUTING MECHANISMS IN THE PREMATURE INFANT ${ }^{1,2}$
}

\author{
By PHILIP L. CALCAGNO, MITCHELL I. RUBIN, AND DAVID H. WEINTRAUB \\ WITH THE TECHNICAL ASSISTANCE OF MARY $\mathrm{K}$. KELLEHER AND
}

MARGARET $H$. STUBBINS

\author{
(From the Statler Research Laboratories of The Children's Hospital of Buffalo and the \\ Department of Pediatrics, The University of Buffalo School of Medicine, \\ Buffalo, N. Y.)
}

(Submitted for publication July 10, 1953; accepted September 25, 1953)

It is known that young premature infants are unable to concentrate urine to the same degree as adults. The following hypotheses have been advanced to explain this difference: (a) A lowered production of antidiuretic hormone (1) ; (b) a reduced response of the distal renal tubule (endorgan) to antidiuretic hormone (2); (c) a decreased rate of solute excretion secondary to a lower rate of glomerular filtration (3).

Heller and Zaimis found that there is a lower concentration of antidiuretic hormone in the pituitary body of newborn infants than in adults, when compared on a body weight basis (1). Yet these authors believe that in spite of this smaller amount of hormone in the pituitary of the newborn infant, there is still a sufficient quantity of the hormone to produce a maximally concentrated urine, if the hormone is released and if the renal tubule of the newborn infant is responsive. Heller (2) also showed that amounts of pituitary extract, which produced a pronounced inhibition of water diuresis in adults, had only a slight and fleeting effect on the kidney of newborn infants. In comparing the response of three premature infants with that of two adults to intravenously administered pitressin during water diuresis, it was found (4) that the extent and duration of the antidiuretic response was less in the premature infant. The third hypothesis, the effect of solute excretion, can be tested by noting the changes in urine osmolarity in response to solute loading. If the lower concentrating capacity during hydropenia were solely a reflection of the lower solute load in the premature infant, then a rise in the osmolar concentration should occur with loading. On the

1 Read in part before the 23rd Annual Meeting of the Society for Pediatric Research, Atlantic City, New Jersey, May, 1953.

2 Aided by grants from the Mead Johnson Company, Evansville, Indiana, and the U. S. Public Health Service. other hand, if the response to loading were similar to the adult but of lesser magnitude, it would suggest that the lower concentrating capacity was due to a deficient tubular response. The experiments reported here were planned to test this hypothesis.

\section{METHODS}

The subjects of these studies were four premature infants weighing approximately 1500 grams but varying in ages from 5 to 23 days. To induce hydropenia they were deprived of water and formula for 12 to 18 hours. Urine aliquots were obtained to determine the maximum urine osmolarity during water deprivation.

Mannitol was used as the loading substance and was given in a 25 per cent solution intravenously. During the first 10 minutes, 180 to 200 milliosmoles per $1.73 \mathrm{M}^{2}$ were given and this was followed by a maintenance infusion of 1 per cent of the total priming dose per minute. Fifteen to 20 minutes were allowed for equilibration of mannitol ; urine was collected under oil for three or more 10-minute periods. Blood samples were drawn before loading, after equilibration, and after the experiments were completed. The osmotic pressure, sodium, chloride and potassium of the urine and blood were determined. Osmotic pressure was determined with the Hill-Baldes apparatus $(5,6)$. Sodium and potassium were determined by a PerkinElmer flame photometer Model 52-A, using an internal lithium standard, and chloride by the method of Sendroy, modified by Van Slyke and Hiller (7). Endogenous creatinine was determined by the method of Hare and Hare (8), inulin by the method of Hubbard and Loomis (9), using the acid mixture for hydrolysis of inulin as modified by Harrison (10). These experiments were repeated on three of the four premature infants after intervals of 5 to 20 days.

\section{RESULTS}

Table I presents the data obtained with mannitol diuresis during hydropenia in four premature infants. The osmotic $\mathrm{U} / \mathrm{P}$ ratio was estimated in these infants prior to mannitol loading. The values ranged from 1.75 to 2.31 with an average value of 2.10. In a group of 12 other premature 
TABLE I

Osmotic diuresis in hydropenic premature infants*

\begin{tabular}{|c|c|c|c|c|c|c|c|c|c|c|c|c|}
\hline \multirow[b]{2}{*}{ Patient } & \multirow{2}{*}{ 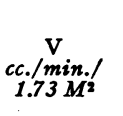 } & \multirow{2}{*}{$\underset{\substack{\text { Us } \\
\text { mo. }}}{\substack{\text { S. } \\
.}}$} & \multirow{2}{*}{ 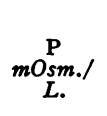 } & \multicolumn{2}{|c|}{$\underset{c c . / m i n . / 1.73 M^{2}}{\mathrm{C}}$} & \multirow{2}{*}{$\begin{array}{c}\text { Osmotic } \\
\text { U/P } \\
\text { ratio }\end{array}$} & \multirow{2}{*}{$\begin{array}{l}\text { Creati- } \\
\text { nine } \\
\text { U/P } \\
\text { ratio }\end{array}$} & \multirow{2}{*}{$\begin{array}{l}\frac{\text { UosmV }}{\text { Posmm }} \\
\text { cc. } . \text { minin. }^{\prime} \\
1.73 \mathrm{M}^{2}\end{array}$} & \multirow{2}{*}{$\begin{array}{c}\mathrm{TcH}_{2} \mathrm{O} \\
c c^{\prime} / \min _{i} / \\
1.73 M^{2}\end{array}$} & \multicolumn{3}{|c|}{ MicroEq./min./1.73 $M^{2}$} \\
\hline & & & & $\mathrm{Cr}$ & I & & & & & $\mathrm{Na}$ & $\mathrm{K}$ & $\mathrm{Cl}$ \\
\hline & 0.59 & 608 & 276 & 43.0 & & 2.20 & 76.0 & 1.30 & 0.71 & 20 & 50 & 25 \\
\hline $\begin{array}{l}\text { Wt. } 1500 \mathrm{Gm} \text {. } \\
\text { SA } 0.140\end{array}$ & $\begin{array}{l}4.08 \\
5.80 \\
6.18\end{array}$ & $\begin{array}{l}460 \\
416 \\
424\end{array}$ & $\frac{7}{308}$ & $\begin{array}{r}143.0 \\
68.0 \\
62.0\end{array}$ & & $\frac{-}{1.37}$ & $\begin{array}{l}78.0 \\
12.1 \\
11.0\end{array}$ & $\begin{array}{l}5.98 \\
7.82 \\
8.50\end{array}$ & $\begin{array}{l}1.90 \\
2.00 \\
2.32\end{array}$ & $\begin{array}{l}280 \\
360 \\
480\end{array}$ & $\begin{array}{r}90 \\
110 \\
140\end{array}$ & $\begin{array}{l}230 \\
270 \\
410\end{array}$ \\
\hline $\begin{array}{l}\mathrm{C}_{\mathrm{I}} \\
\text { Age } 5 \text { days }\end{array}$ & & 588 & 335 & 14.0 & & $\begin{array}{r}1.75 \\
\text { annitol } 2\end{array}$ & $\begin{array}{l}72.0 \\
25 \% \text { I.V. }\end{array}$ & 0.32 & 0.23 & 12 & 6 & - \\
\hline $\begin{array}{l}\text { Wt. } 1560 \mathrm{Gm} \text {. } \\
\text { SA } 0.140\end{array}$ & $\begin{array}{l}3.46 \\
2.84\end{array}$ & $\begin{array}{l}480 \\
512\end{array}$ & 384 & $\begin{array}{l}27.0 \\
23.0\end{array}$ & & $\underline{1.25}$ & $\begin{array}{l}8.3 \\
8.7\end{array}$ & $\begin{array}{l}4.32 \\
3.77\end{array}$ & $\begin{array}{l}0.86 \\
0.93\end{array}$ & $\begin{array}{l}320 \\
250\end{array}$ & $\begin{array}{l}30 \\
20\end{array}$ & $\begin{array}{l}190 \\
160\end{array}$ \\
\hline รe 2 & & 606 & 262 & 17.0 & & $\begin{array}{r}2.31 \\
\text { anitol } 2\end{array}$ & $25 \%$ I.V. & 0.26 & 0.15 & 6 & 9 & 6 \\
\hline $\begin{array}{l}\text { Wt. } 1750 \mathrm{Gm} \text {. } \\
\text { SA } 0.149\end{array}$ & $\begin{array}{l}4.63 \\
4.86\end{array}$ & $\begin{array}{l}420 \\
416\end{array}$ & $\overline{326}$ & $\begin{array}{l}31.0 \\
38.2\end{array}$ & & $\overline{1.27}$ & $\begin{array}{l}6.9 \\
7.8\end{array}$ & $\begin{array}{l}5.95 \\
6.19\end{array}$ & $\begin{array}{l}1.52 \\
1.33\end{array}$ & $\begin{array}{l}312 \\
286\end{array}$ & $\begin{array}{l}87 \\
85\end{array}$ & $\begin{array}{l}227 \\
372\end{array}$ \\
\hline $\begin{array}{l}\text { P } \\
\text { Age } 27 \text { days } \\
\text { Wt. } 1600 \mathrm{Gm} . \\
\text { SA } 0.139 \\
\text { Hydropenic }\end{array}$ & $\begin{array}{l}0.47 \\
3.91 \\
4.62 \\
5.32 \\
5.56\end{array}$ & $\begin{array}{c}586 \\
-362 \\
356 \\
331 \\
340\end{array}$ & $\begin{array}{l}285 \\
\frac{344}{344}\end{array}$ & $\begin{array}{l}22.0 \\
-\overline{29.0} \\
26.0 \\
\overline{35.0}\end{array}$ & & $\begin{array}{c}2.07 \\
\text { innitol } \\
1.05 \\
\overline{-} \\
0.99\end{array}$ & $\begin{array}{c}47.0 \\
25 \% \text { I.V. } \\
7.4 \\
5.6 \\
\frac{5.8}{4.8}\end{array}$ & $\begin{array}{l}0.97 \\
-1.11 \\
4.110 \\
5.19 \\
5.49\end{array}$ & $\begin{array}{r}0.20 \\
0.18 \\
+0.13 \\
+0.06\end{array}$ & $\begin{array}{l}253 \\
308 \\
424 \\
448\end{array}$ & $\begin{array}{l}54 \\
55 \\
65 \\
64\end{array}$ & $\begin{array}{l}272 \\
271 \\
308 \\
309\end{array}$ \\
\hline $\begin{array}{l}\text { L } \\
\text { Age } 8 \text { days }\end{array}$ & 0.52 & 628 & 311 & 16.6 & $\begin{array}{l}14.0 \\
--1\end{array}$ & $\begin{array}{r}2.02 \\
\text { nnitol } 2\end{array}$ & $25 \%$ I.V. & 0.72 & 0.20 & 37 & 29 & 28 \\
\hline $\begin{array}{l}\text { Wt. } 1525 \mathrm{Gm} \text {. } \\
\text { SA } 0.137\end{array}$ & $\begin{array}{l}2.53 \\
3.08 \\
3.67\end{array}$ & $\begin{array}{l}464 \\
470 \\
444\end{array}$ & & $\begin{array}{l}33.4 \\
40.7 \\
43.1\end{array}$ & $\begin{array}{l}17.9 \\
21.0 \\
23.2\end{array}$ & $\bar{z}$ & $\begin{array}{l}13.4 \\
13.3 \\
11.5\end{array}$ & $\begin{array}{l}3.43 \\
4.23 \\
4.77\end{array}$ & $\begin{array}{l}0.91 \\
1.16 \\
1.10\end{array}$ & $\begin{array}{l}118 \\
132 \\
181\end{array}$ & $\begin{array}{l}35 \\
33 \\
33\end{array}$ & $\begin{array}{l}58 \\
6 \\
9\end{array}$ \\
\hline & $\begin{array}{l}-\overline{4} .60 \\
4.18 \\
5.32\end{array}$ & $\begin{array}{l}-- \\
448 \\
432 \\
410\end{array}$ & 342 & $\begin{array}{l}\text { Pitres } \\
52.5 \\
40.7 \\
50.2\end{array}$ & $\begin{array}{c}1 \mathrm{c} \mathrm{mi} \\
24.2 \\
24.0 \\
28.9\end{array}$ & $\frac{1}{1.20}$ & $\begin{array}{c}\text { ml. dilue } \\
10.6 \\
9.8 \\
9.4\end{array}$ & $\begin{array}{c}\text { ent given } \\
6.03 \\
5.23 \\
6.34\end{array}$ & $\begin{array}{r}\text { I.V. } \overline{-} \\
2.06 \\
1.81 \\
2.18\end{array}$ & $\begin{array}{l}\overline{273} \\
243 \\
288\end{array}$ & $\begin{array}{l}37 \\
28 \\
30\end{array}$ & $\begin{array}{l}\overline{102} \\
72 \\
200\end{array}$ \\
\hline $\begin{array}{l}\mathrm{L} \\
28 \text { days } \\
\text { Wt. } 2010 \mathrm{Gm} .\end{array}$ & 0.40 & $\begin{array}{l}700 \\
648\end{array}$ & $\begin{array}{l}306 \\
302\end{array}$ & $\overline{34.7}$ & $\overline{30.0}$ & $\begin{array}{l}2.28 \\
2.15\end{array}$ & 75.0 & $\overline{0.89}$ & $\overline{0.49}$ & $\overline{10}$ & $\overline{35}$ & $\overline{13}$ \\
\hline & $\begin{array}{l}2.74 \\
2.53 \\
-\end{array}$ & $\begin{array}{r}508 \\
488 \\
--\end{array}$ & 320 & $\begin{array}{l}54.9 \\
58.4\end{array}$ & $\begin{array}{l}32.7 \\
34.2\end{array}$ & 1.59 & $\begin{array}{l}20.0 \\
22.3\end{array}$ & $\begin{array}{l}4.21 \\
3.76\end{array}$ & $\begin{array}{l}1.57 \\
1.23 \\
\end{array}$ & $\begin{array}{l}73 \\
70\end{array}$ & $\begin{array}{l}70 \\
53\end{array}$ & $\begin{array}{l}80 \\
61\end{array}$ \\
\hline & $\begin{array}{l}3.59 \\
3.20\end{array}$ & $\begin{array}{l}472 \\
472\end{array}$ & $\overline{330}$ & $\begin{array}{l}\text { Fitres } \\
58.5 \\
51.6\end{array}$ & $\begin{array}{l}36.3 \\
30.0\end{array}$ & $\frac{11 \text { in }}{1.44}$ & $\begin{array}{l}16.3 \\
16.3\end{array}$ & $\begin{array}{l}\text { nt give } \\
5.15 \\
4.55\end{array}$ & $\begin{array}{r}1.8-5 \\
1.36 \\
1.38\end{array}$ & $\begin{array}{l}118 \\
127\end{array}$ & $\begin{array}{l}58 \\
53\end{array}$ & 58 \\
\hline
\end{tabular}

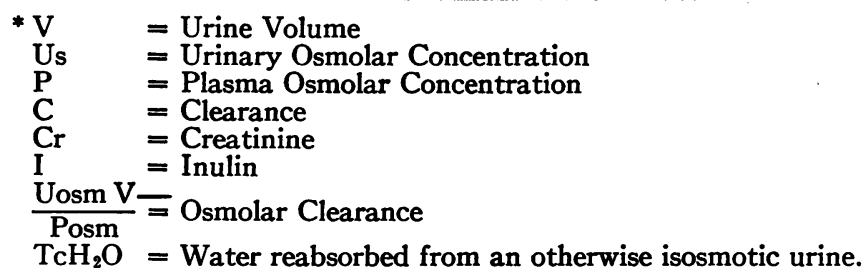

infants following an 18-hour period of food and water deprivation, the average osmotic $U / P$ ratio was found to be 2.49 .

The urine flow before loading varied between 0.11 to $0.59 \mathrm{ml}$. per min. per $1.73 \mathrm{M}^{2}$ and increased with mannitol loading to as much as $6.18 \mathrm{ml}$. per min. per $1.73 \mathrm{M}^{2}$. With loading, urine osmolar concentrations fell from an average value of 617 mOsm. per L. (in the four infants) to an average value of 429 mOsm. per $\mathrm{L}$. The increment in plasma osmolarity during the mannitol infusion ranged from 24 to $64 \mathrm{mOsm}$. per L.

The osmolar clearance (Cosm) calculated from the urine and plasma osmolarity represents the number of milliliters of plasma cleared of its contained osmoles (isosmotic) per minute. The difference between the osmolar clearance and urine flow indicates the quantity of water which would 
have to be reabsorbed from an isosmotic tubular urine to produce a concentrated urine. This quantity of water reabsorbed measured in ml. per min. has been designated by Wesson and Anslow by the symbol $\mathrm{TcH}_{2} \mathrm{O}^{3}$ At high urine flows, in the presence of varying osmolar clearances the $\mathrm{TcH}_{2} \mathrm{O}$ appears to be a relatively constant value for each patient. (Patient P. did not show a significant $\mathrm{TcH}_{2} \mathrm{O}$. The urine osmolarity of this infant during loading was isosmotic with the plasma osmolar concentration.) $\quad \mathrm{TcH}_{2} \mathrm{O}$ values above 2.32 which is approximately one half that of the mean adult value, were not obtained in any of these infants.

To determine whether or not this lowered water reabsorption was due to a deficiency in $\mathrm{ADH}$ production or insensitivity of tubular response to $\mathrm{ADH}$, the following experiment was performed. After collecting urine for three periods during mannitol loading in Patient L., pitressin was given as a single injection intravenously and further collections made. The pitressin (given in a dosage of 24 milliunits per $\mathrm{M}^{2}$ ) produced no further increase in water reabsorption $\left(\mathrm{TcH}_{2} \mathrm{O}\right)$ or urine concentration. A slight increase in $\mathrm{TcH}_{2} \mathrm{O}$ was noted with pitressin when this infant was younger.

Sodium excretions increased as much as 64 fold over the preliminary rates of 6 to $37 \mathrm{mEq}$. per min. per $1.73 \mathrm{M}^{2}$ amounting to around 24 per cent of the total osmolar excretion. Chloride excretions also rose in significant amounts. In contrast, potassium excretions showed only a four to five fold increase during mannitol loading and comprised about 4 per cent of the total osmolar excretion.

\section{DISCUSSION}

The observed fall in the urine osmolarity with mannitol loading in hydropenic premature infants is similar to the type of response seen in adults (12). The response in the premature infant differs in that the urine osmolarity starts at a lower level than it does in the adult and more closely approaches the plasma osmolar concentration during the diuresis.

It has been presumed that during osmotic loading in hydropenic states, there is a maximal $\mathrm{ADH}$

8 This fraction of reabsorbed water has been defined by Brodsky as "water economy" (11).

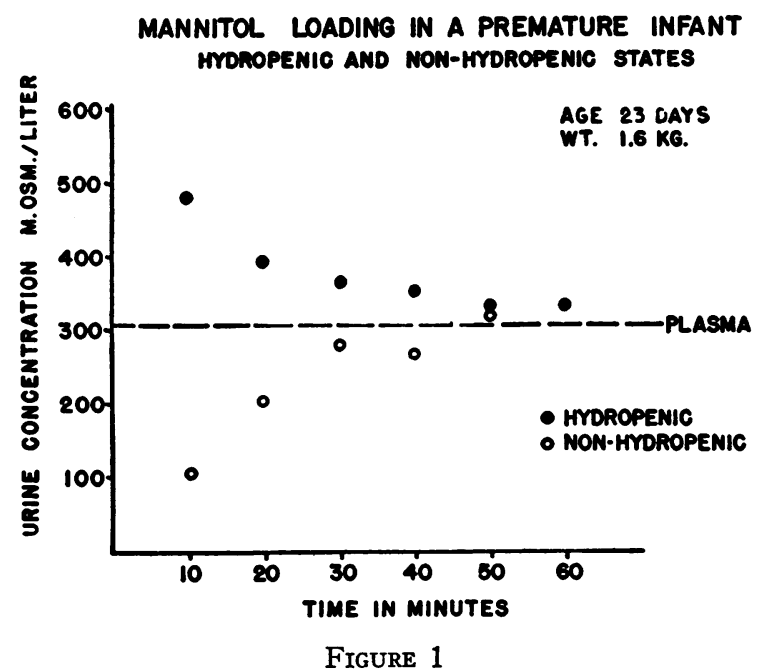

effect (13). The lack of further significant antidiuresis when pitressin was given in this study would seem to support this belief. If the decreased water reabsorption in the premature infant were due to insufficient $\mathrm{ADH}$ alone, the pitressin should have produced significant antidiuresis, which was not the case. It was shown (4) under other circumstances in the premature infant that there was a lessened responsiveness of the tubules to pitressin stimulation when compared to the adult. Our data, showing an inappreciable pitressin effect during hydropenia, suggest that the lowered concentrating capacity of the premature infant is probably of tubular (end-organ) origin.

In contrast to our data, Dean and McCance (14) showed that newborn infants respond with a rise in urine osmolarity when loaded with hypertonic sodium chloride or urea solutions. In order to elucidate these differences in results, the following experiment was done (Figure 1): One infant was "loaded" with mannitol during hydropenia and again four days later two hours after a $30-\mathrm{ml}$. feeding. The response to mannitol loading after the $30-\mathrm{ml}$. feeding was reversed from the usual seen during hydropenia and similar to that of the babies studied by Dean and McCance (14). Thus, under hydropenic conditions, this premature infant showed a fall in urine osmolarity with osmotic loading; and in the non-hydropenic state this same infant showed a rise in urine osmolarity.

It is of interest that the premature infant with plasma osmolar concentrations comparable to the adult has an osmolar clearance of about one third 
CONCENTRATING MECHANISM IN PREMATURE INFANTS AT HIGII URINE FLOW

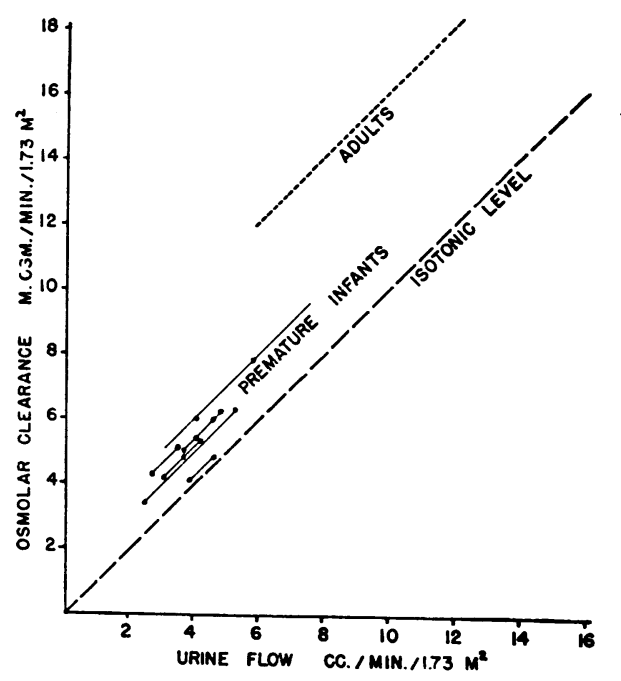

Figurs 2

to one half the adult value $(8.5 \mathrm{ml}$. per min. per $1.73 \mathrm{M}^{2}$ as compared to 15 to $25 \mathrm{ml}$. per min. per $1.73 \mathrm{M}^{2}$ ). This is apparently dependent upon the lower glomerular filtration rate in the premature infant. Nevertheless we can presume that his glomerular filtrate has an osmolar concentration equal to that of the adult at comparable plasma osmolar concentrations. Since the maximal osmolar concentration of his urine during dehydration is about half that of the adult (osmotic U/P ratio of about 2.10 to the adult value of 4 ), this lack of concentrating capacity cannot then be ascribed to a deficient filtered osmolar load, but to decreased tubular water reabsorption.

Figure 2 relates the osmolar clearance to urine volume. Although there is a variable urine flow and osmolar clearance, the quantity of water reabsorbed $\left(\mathrm{TcH}_{2} \mathrm{O}\right)$ appears to be a relatively constant value for each infant. This value for $\mathrm{TcH}_{2} \mathrm{O}$ at high urine flows is about one half to one third of that observed in the adult. Conversely then, at a given osmolar load these infants excrete a larger volume of water. Two of these premature infants ( $C$ and $L$ ) tested about two weeks after the initial observation were found to have a $\mathrm{TcH}_{2} \mathrm{O}$ slightly greater than that obtained during the first observation, indicating maturing function in this relatively short period of time.

It would appear that the ultimate concentration of the urine during hydropenia is a function of the antidiuretic activity of $\mathrm{ADH}$, the osmolar concentration of the tubular urine, and the responsiveness of the end-organ (tubular cells). At high urine flows, under osmotic diuresis, there is a relatively constant volume of water reabsorbed $\left(\mathrm{TcH}_{2} \mathrm{O}\right)$. This volume of water in the premature infant is less than that of the adult but increases rapidly with aging. At low urine flows it has been suggested that the significant factor limiting water reabsorption is the osmotic concentration in the tubular fluid (15) (osmotic U/P ratio). This lowered $\mathrm{TcH}_{2} \mathrm{O}$ and osmotic $\mathrm{U} / \mathrm{P}$ ratio in the premature infant are probably dependent upon the physiologic unresponsiveness of the immature tubules.

Figure 3 demonstrates the rise in the glomerular filtration rate during loading with mannitol in one of the babies. A rise in glomerular filtration rate as measured by inulin clearance was also obtained in the two infants studied by Dean and McCance (14) when hypertonic solutions of sodium chloride and urea were administered. In contrast to the premature, the adult shows no rise in glomerular filtration rate with mannitol loading (16). This variation in response of the premature infant once again demonstrates the labile nature of his glomerular apparatus. This variability has been previously demonstrated with a fall in glomerular filtration rate during dehydration (17), in contrast to the adult response (18). The creatinine to inulin ratio, although within the normal range during the preloading phase, showed

PERCENTAge Change in glomerular filtration RATE DURING MANNITOL LOADING

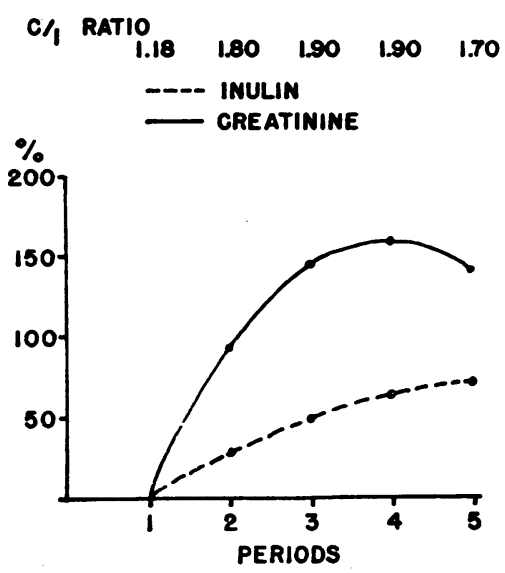

FIGURE 3 
WATER DIURESIS IN A PREMATURE INFANT
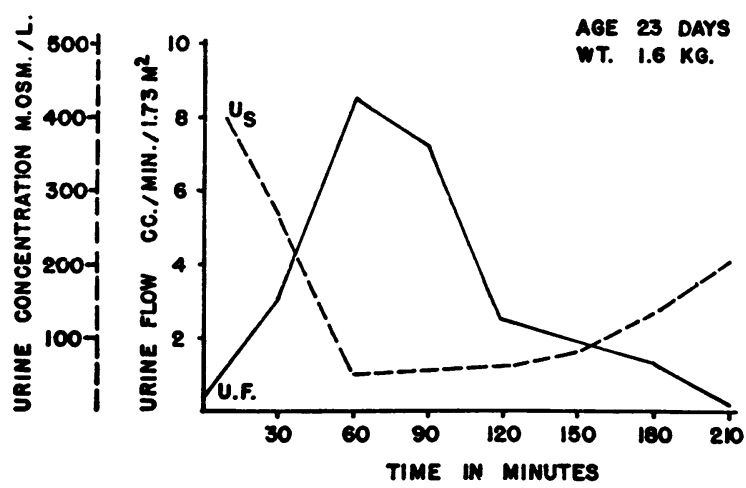

Figure 4

a rise to 1.90 with mannitol loading. Accepting inulin as a measure of glomerular filtration rate, the higher creatinine to inulin ratio may be interpreted as showing tubular excretion of creatinine during the loading period.

When excretions of sodium are related to the total osmolar excretions, it is found that the urinary sodium in three of the four premature infants comprises a higher percentage (average 15 per cent) of the osmolar composition than was seen in the adults (average 10 per cent) studied by Brodsky (11). The remaining infant did not show this tendency for greater sodium loss. These data suggest that the mechanism for tubular sodium reabsorption in the premature baby during osmotic diuresis is interfered with to a greater extent than in the adult. This may have important clinical implications. The chloride excretion pattern was similar to that of sodium in relation to the total osmolar excretion. Potassium excretion did not follow the patterns of sodium and chloride. These variations in electrolyte excretion are similar to those found in the adult (19).

These premature infants were also given a single water load (approximately $525 \mathrm{ml}$. per $\mathrm{M}^{2}$ ). A typical response to water loading is shown in Figure 4. The maximum urine flow obtained in this patient was $8.3 \mathrm{ml}$. per min. per $1.73 \mathrm{M}^{2}$, while the adult under similar conditions excretes between 12 and $14 \mathrm{ml}$. per min. per $1.73 \mathrm{M}^{2}$. The minimal concentration of osmoles in the urine of the premature infant was about 50 milliosmoles per liter, a value comparable to that obtained in the adult. This finding of a maximal renal water ex- cretion rate of $20 \mathrm{ml}$. per osmole for both the premature and the adult is consistent with the data reported previously (4). This lowered urine flow in the premature infant during loading with an average value of $8.2 \mathrm{cc}$. per min. per $1.73 \mathrm{M}^{2}$ parallels his decreased osmolar clearance. The fact that premature infant during water diuresis reaches osmolar concentrations as low as does the adult ( $50 \mathrm{mOsm}$. per L. or $20 \mathrm{ml}$. per mOsm.) at a time when his concentrating mechanism $\left(\mathrm{TcH}_{2} \mathrm{O}\right)$ is less than that of the adult, suggests that these two functions may involve separate areas of tubular activity.

\section{SUMMARY}

1. During osmotic diuresis in the hydropenic state, the premature infant reabsorbs a smaller quantity of fixed water than does the adult under similar circumstances and, therefore, excretes a urine of lower osmolarity. Under the circumstances described, the constant volume of reabsorbed water measured as $\mathrm{TcH}_{2} \mathrm{O}$ appears to be a factor limiting concentration during high urine flows. The premature infant attains a urine osmotic $U / P$ ratio of about 2.5 during water deprivation. Adults under similar circumstances attain a value of about 4. This lowered $\mathrm{TcH}_{2} \mathrm{O}$ and osmotic $U / P$ ratio of the premature infant are probably dependent upon the immaturity of renal tubular function.

2. There is a variable rise in glomerular filtration rate during osmotic (mannitol) loading and a rise in the creatinine to inulin ratio.

3. Sodium is excreted at a higher percentage of the total urinary osmoles in premature infants than is found in adults during osmotic loading.

4. These same premature infants during water diuresis dilute their urine to values comparable to the adult, suggesting that the concentrating and diluting mechanisms of the kidney in the premature infant mature at different rates, and may involve different functional segments of the tubule.

\section{REFERENCES}

1. Heller, H., and Zaimis, E. J., The antidiuretic and oxytocic hormones in the posterior pituitary glands of new born infants and adults. J. Physiol., 1949, 109, 162.

2. Heller, $H$., The renal function of newborn infants. J. Physiol., 1944, 102, 429. 
3. Barnett, H. L., and Vesterdal, J., The physiologic and clinical significance of immaturity of kidney function in young infants. J. Pediat., 1953, 42, 99.

4. Barnett, H. L., Vesterdal, J., McNamara, H., and Lauson, H. D., Renal water excretion in premature infants. J. Clin. Invest., 1952, 31, 1069.

5. Baldes, E. J., A micromethod of measuring osmotic pressure. J. Scient. Instr., 1934, 11, 223.

6. Hill, A. V., A thermal method of measuring the vapor pressure of an aqueous solution. Proc. Roy. Soc., London, s.A., 1930, 127, 9, (April 1).

7. Hawk, P. B., and Bergeim, O., Practical Physiological Chemistry, ed. 11, Philadelphia, P. Blakiston's Son and Co., Inc., 1937.

8. Hare, R. S., Endogenous creatinine in serum and urine. Proc. Soc. Exper. Biol. \& Med., 1950, 74, 148.

9. Hubbard, R. S., and Loomis, T. A., The determination of inulin. J. Biol. Chem., 1942, 145, 641.

10. Harrison, H. E., Modification of the diphenylamine method for determination of inulin. Proc. Soc. Exper. Biol. \& Med., 1942, 49, 111.

11. Brodsky, W. A., Osmotic diuresis in hydropenic man. Methods in Med. Research, 1952, 5, 192.

12. Wesson, L. G., Jr., and Anslow, W. P., Jr., Effect of osmotic and mercurial diuresis on simultaneous water diuresis. Am. J. Physiol., 1952, 170, 255.
13. Rapoport, S., Brodsky, W. A., and West, C. D., Excretion of solutes and osmotic work of the "resting" kidney of hydropenic man. Am. J. Physiol., 1949, 157, 357.

14. Dean, R. F. A., and McCance, R. A., The renal responses of infants and adults to the administration of hypertonic solution of sodium chloride and urea. J. Physiol., 1949, 109, 81.

15. Chesley, L. C., Renal excretion at low urine volumes and the mechanism of oliguria. J. Clin. Invest., 1938, 17, 591.

16. Brodsky, W. A., Rapoport, S., Graubarth, H. N., and Levkoff, A. H., Osmotic diuresis as a measurement of renal function in man. J. App. Physiol., 1952, $5,62$.

17. Calcagno, P. L., and Rubin, M. I., Effect of dehydration produced by water deprivation, diarrhea and vomiting on renal function in infants. Pediatrics, 1951, 7, 328.

18. Black, D. A. K., McCance, R. A., and Young, W. F., Function of the kidney in dehydration. Nature, 1942, 150, 461.

19. Brodsky, W. A., and Rapoport, S., The mechanism of polyuria of diabetes insipidus in man: The effect of osmotic loading. J. Clin. Invest., 1951, 30, 282. 